\title{
How conductance distributions are shaped by activity-dependent regulation rules
}

\author{
Timothy O'Leary ${ }^{*}$, Alex H Williams, Jonathan S Caplan, Eve Marder \\ From Twenty Second Annual Computational Neuroscience Meeting: CNS*2013 \\ Paris, France. 13-18 July 2013
}

Neurons co-express a multitude of different ion channels that determine the electrophysiological behaviour of the cell. Recent experimental observations have revealed that the expression of different ion channels varies dramatically within neurons of a defined type, even when these neurons exhibit stereotyped electrical properties [1-5]. This variability has a structure visible in the correlations between different ion channel expression levels. Nonetheless,, the underlying mechanism that determines these correlations is unknown, nor is understood how these correlations can coexist with activity-dependent regulation mechanisms that are also known to exist in neurons [6]. We show that these observations are logical consequences of relatively simple control mechanisms that couple the expression levels of individual conductances to a cell-intrinsic readout of activity [7]. Crucially, these correlations are not visible when conductance space is searched to find combinations of conductances that give target behaviour. Therefore, activity-dependent regulation mechanisms constrain the solution space of potential combinations of membrane conductances to a characteristic subset. Furthermore, we show how the shape of the conductance distribution of a population of neurons is determined by the relative rates of expression of different conductances. Finally, degeneracy in the function of multiple ion channels means that regulation mechanisms can have widely-variable parameters yet remain stable; this is exemplified by tolerance to 'antihomeostatic' regulation of a subset of conductances.

\section{Acknowledgements \\ Supported by MH46742 and the Swartz Foundation.}

Published: 8 July 2013

\footnotetext{
* Correspondence: toleary@brandeis.edu

Volen Center for Complex Systems, Brandeis University, Waltham, MA 02454,
} USA

C 2013 O'Leary et al; licensee BioMed Central Ltd. This is an Open Access article distributed under the terms of the Creative Commons

\section{References}

1. Liss $B$, Roeper J: Correlating function and gene expression of individual basal ganglia neurons. Trends Neurosci 2004, 27(8):475-481.

2. Schulz DJ, Goaillard JM, Marder E: Variable channel expression in identified single and electrically coupled neurons in different animals. Nat Neurosci 2006, 9(3):356-362.

3. Schulz DJ, Goaillard JM, Marder EE: Quantitative expression profiling of identified neurons reveals cell-specific constraints on highly variable levels of gene expression. P Natl Acad Sci USA 2007, 104(32):13187-13191.

4. Tobin AE, Cruz-Bermudez ND, Marder E, Schulz DJ: Correlations in lon Channel mRNA in Rhythmically Active Neurons. PloS one 2009, 4(8).

5. Toledo-Rodriguez M, Blumenfeld B, Wu CZ, Luo JY, Attali B, Goodman P, Markram H: Correlation maps allow neuronal electrical properties to be predicted from single-cell gene expression profiles in rat neocortex. Cereb Cortex 2004, 14(12):1310-1327.

6. Marder E, Goaillard JM: Variability, compensation and homeostasis in neuron and network function. Nature reviews 2006, 7(7):563-574.

7. Liu Z, Golowasch J, Marder E, Abbott LF: A model neuron with activitydependent conductances regulated by multiple calcium sensors. J Neurosci 1998, 18(7):2309-2320.

\section{doi:10.1186/1471-2202-14-S1-P258}

Cite this article as: O'Leary et al:: How conductance distributions are shaped by activity-dependent regulation rules. BMC Neuroscience 2013 14(Suppl 1):P258. and take full advantage of:

- Convenient online submission

- Thorough peer review

- No space constraints or color figure charges

- Immediate publication on acceptance

- Inclusion in PubMed, CAS, Scopus and Google Scholar

- Research which is freely available for redistribution 